\title{
Molecular biology on a microfluidic chip
}

\author{
Jong Wook Hong ${ }^{1,4}$, Yan Chen ${ }^{2}$, W French Anderson ${ }^{1,3}$ and \\ Stephen R Quake ${ }^{1,5}$ \\ ${ }^{1}$ Department of Applied Physics, California Institute of Technology, Pasadena, CA 91125, USA \\ ${ }^{2}$ Bioengineering Option, California Institute of Technology, Pasadena, CA 91125, USA \\ ${ }^{3}$ Gene Therapy Laboratories, University of Southern California, Keck School of Medicine, \\ Los Angeles, CA 90033, USA \\ E-mail: quake@ stanford.edu
}

Received 26 August 2005, in final form 24 November 2005

Published 19 April 2006

Online at stacks.iop.org/JPhysCM/18/S691

\begin{abstract}
We have developed microfluidic chips for automating molecular biology processes such as gene ligation and gene transformation from nanolitre sample volumes with parallel architecture. Unlike conventional tube methods with cumbersome pipetting procedures, all processes, including metering of samples, ligation and transformation, were carried out in the microfluidic chips through pneumatic control of the nanofluid. The microfluidic devices presented here offer an illustration of some of the basic physics that arises when trying to miniaturize and automate biological techniques.
\end{abstract}

\section{Introduction}

Microfluidics is a multidisciplinary field comprising physics, chemistry, engineering, and biotechnology; it refers to the study and manipulation of tiny volumes, nanolitres or picolitres, of liquid [1]. A major application of microfluidics is biological automation, as this involves scaling fluid manipulations from millilitres and microlitres to the nanolitre scale. This scaling is often accompanied by interesting changes in the basic fluid physics [2], and these physical effects often introduce complications. For example, it is well known that due to the low Reynolds number of microfluidic devices, mixing is a challenge. Another example is effects derived from the large surface-area-to-volume ratio in such devices. Here we use a fundamental process in molecular biology (creation of recombinant DNA) as an example to examine how various physical effects must be taken into consideration when creating microfluidic devices for biological automation.

4 Present address: Materials Engineering Program, Department of Mechanical Engineering, Auburn University, Auburn, AL 36849, USA.

5 Author to whom any correspondence should be addressed. Present address: Department of Bioengineering, Stanford University, Palo Alto, CA 94305, USA. 
Construction of recombinant DNA and the transformation of the genetic material into specific target cells are indispensable techniques for molecular biology. Since the first trial of gene transformation with bacterial cells in 1970 by Mendel and Higa [3], many variations of this basic technique have been developed for biology, medicine and biotechnology applications $[4,5]$. The basic idea of transformation is the insertion of target DNA by heat shock into competent bacterial cells made competent by calcium chloride treatment. Another method instead of heat shock is electroporation (or electrotransformation) $[6,7]$ that applies a high electrical current for a very short time around the mixture of the target cell and target gene. This electrical shock allows insertion of charged molecules such as dyes and nucleic acids into the cells. There are other methods like microinjection, which is mainly restricted to relatively large mammalian cells instead of bacterial cells.

There have been several recent reports about the insertion of specific genes using microfabricated fluidic systems with the combination of electrical voltage control or microelectrodes based on hard materials such as silicon or glass [8-10]. The main control method of the fluid or the sample is electrical control, which is usually appropriate for the handling of several microlitres of samples. These electroporation-based gene transfer methods may not be suitable for nanolitre volumes of samples although they do allow samples and reagents to be reduced down to several microlitres compared to the conventional bench-top tube methods. Here, we report a microfluidic platform for ligation and transformation with nanolitre sample volumes. The platform uses micromechanical valves fabricated by multilayer soft lithography $[11,12]$, which has been applied to the construction of microfluidic systems for the biotechnology applications such as cell sorting [13], microchip polymerase chain reaction (PCR) [14], and nucleic acid purification [15] as well as biophysical studies of protein crystallization [16]. In this paper, we will describe the ligation of a specific gene into a plasmid and transformation of target genes into competent cells on microfluidic systems. We will also discuss how both the fluid physics and the mechanical properties of the valves affect this process.

\section{Materials and methods}

\subsection{Microfabrication}

Chips were fabricated by multilayer soft lithography [11, 17]. Mask designs were created with the CAD program FluidArchitect (Fluidigm, South San Francisco, CA) and transferred to highresolution transparency masks (3389 dpi). The dimensions of the fluidic channels are $100 \mu \mathrm{m}$ in width and $10 \mu \mathrm{m}$ in depth, while the valve actuation channels are typically $200 \mu \mathrm{m}$ in width and $15 \mu \mathrm{m}$ in depth.

The ligation chip, as shown in figure 1, within $20 \mathrm{~mm} \times 20 \mathrm{~mm}$ space, had 12 fluidic access vias, 30 valves and 9 actuation vias that allow microfluidic flow and control. The transformation chip, as shown in figure 2, within $20 \mathrm{~mm} \times 20 \mathrm{~mm}$ space, had 8 fluidic access vias, 47 valves and 11 actuation vias that allow microfluidic flow and control. Mask moulds for the fluidic channels were made by spin-coating positive photoresist (Shipley SJR 5740) on a silicon wafer with $2000 \mathrm{rpm}$ for $1 \mathrm{~min}$, followed by mask exposure and development. These mould channels were rounded at $135{ }^{\circ} \mathrm{C}$ for $15 \mathrm{~min}$ to create a geometry that allows full valve closure. Another mould for the actuation layer was made by spinning photoresist on a separate wafer at $1600 \mathrm{rpm}$ for $1 \mathrm{~min}$ with a resulting height of $12 \mu \mathrm{m}$, followed by mask exposure and development. The devices were fabricated by bonding together two layers of two-part cure silicone (GE Silicone RTV615) cast from the photoresist moulds. The bottom layer of the device, containing the flow channels, was spin coated with 20:1 parts A:B RTV615 at $2400 \mathrm{rpm}$ for $1 \mathrm{~min}$, and the resulting 
A

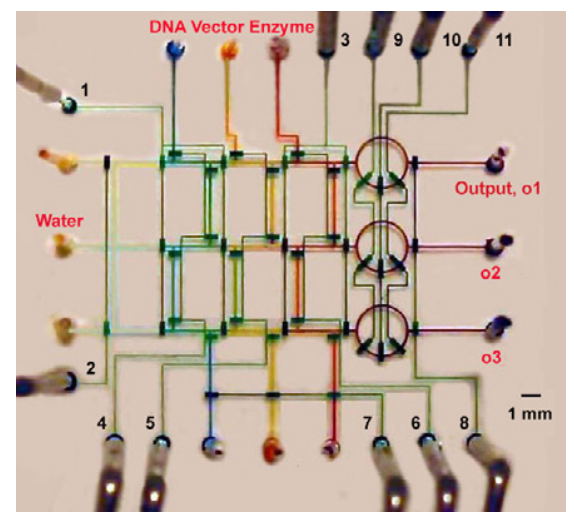

B
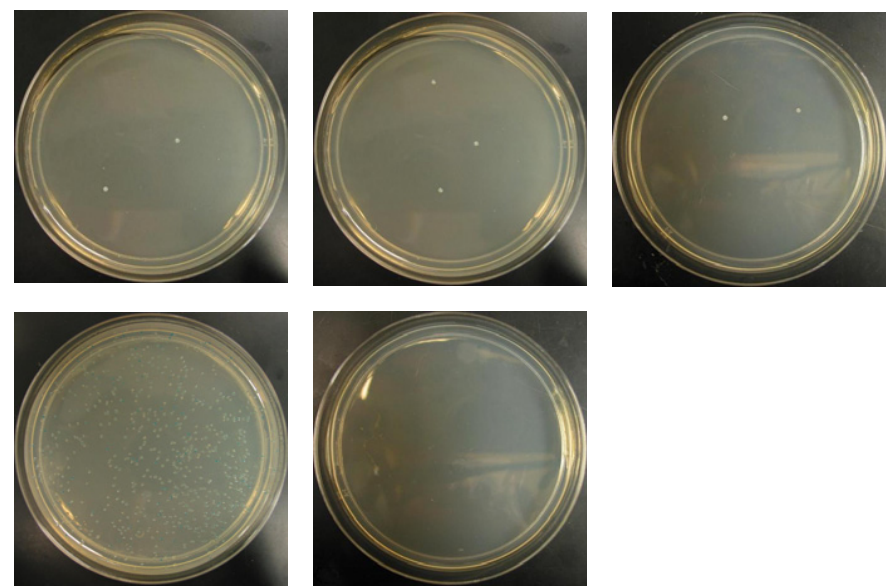

C

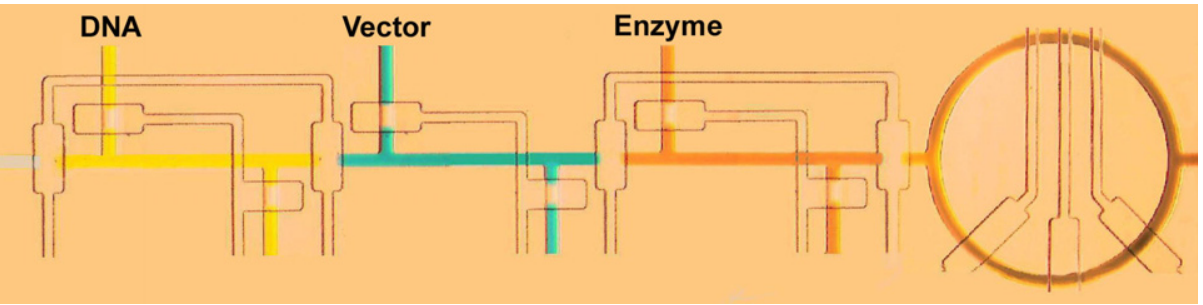

Figure 1. Gene ligation chip. (A) A picture of the gene ligation chip. The fluid channels are filled by different food colouring according to the functionality. The control channels are filled by green food colouring. The fluid ports are names; the control ports are numbered. (B) Results of the ligation from three parallel processes on a chip with positive and negative controls. Three parallel chip experiments are shown in the top row, while the bottom row shows positive (off chip) and negative (target DNA withheld on chip) controls. Ligated colonies cultured on an ampicillin containing agar medium with blue and white screening method. After ligation on chip, transformation was carried out with the conventional tube method to evaluate the ligation efficiency. (C) Part of the chip taken by optical microscope for the single ligation process. Different food colourings represent different potential substrates, such as DNA (yellow), vector (blue), and enzyme (red), and the mixture of yellow, blue, and red colouring in the $6 \mathrm{nl}$ rotary mixer. All the control valves are filled by water in this case, unlike in (A). 
A

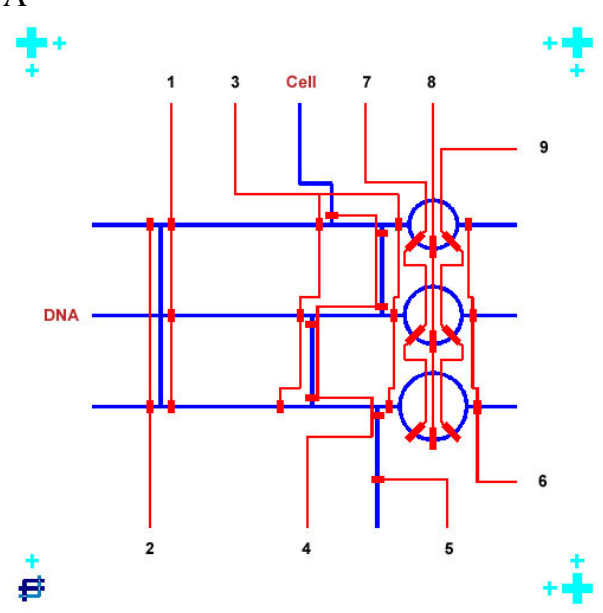

B

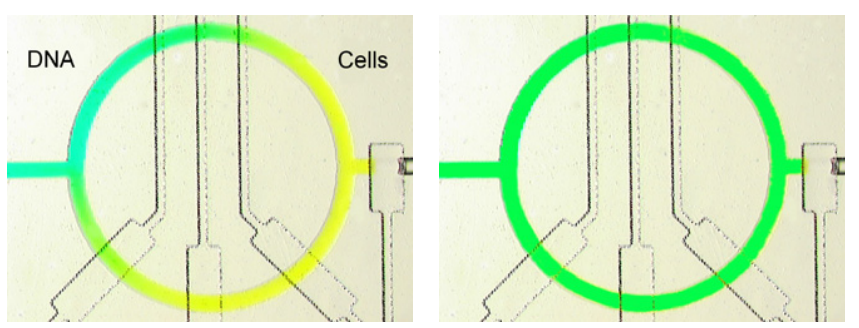

$\mathrm{C}$
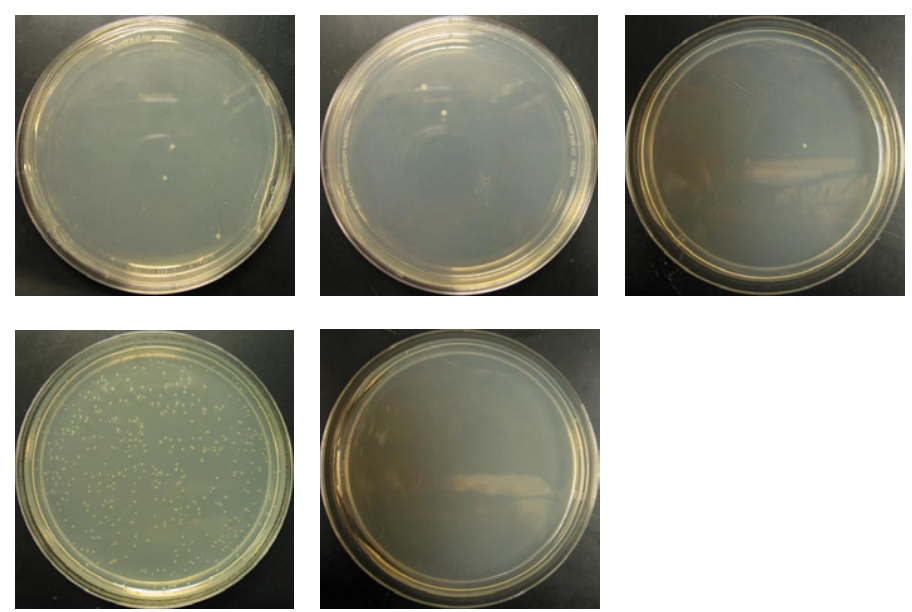

Figure 2. Gene transformation chip. (A) Layout of the microfluidic chip. The blue lines represent the $100 \mu \mathrm{m}$ wide fluid channel, and the red lines are the $100 \mu \mathrm{m}$ wide control channels. The fluid ports are names; the control ports are numbered. (B) $5 \mathrm{nl}$ of a micromixer before (left) and after (right) the mixing. The blue stands for DNA and the yellow for cells. (C) On chip transformed colonies cultured on an ampicillin containing agar medium after the recovery from the chip. Three parallel transformations (top) and positive and negative controls (bottom).

silicone layer was an $11 \mu \mathrm{m}$ thick film. The top layer of the device, containing the actuation channels, was cast as a thick layer ( $5 \mathrm{~mm}$ thick) with 5:1 parts A:B RTV615 using a separate 
mould. The two layers were initially cured for $45 \mathrm{~min}$ at $80^{\circ} \mathrm{C}$. Actuation channel interconnect holes were then punched through the thick layer with a 20 gauge luer stub, after which it was sealed, channel side down, on the thin layer, after aligning the respective channel networks with an optical microscope. Bonding between the assembled layers was accomplished by curing the assembled devices at $80^{\circ} \mathrm{C}$ for more than $90 \mathrm{~min}$, followed by punching the fluidic channel interconnects. The resulting devices were cut to size and mounted on RCA cleaned cover slips (No. $1,24 \mathrm{~mm} \times 50 \mathrm{~mm}$ ), followed by incubation at $80^{\circ} \mathrm{C}$ overnight to promote adhesion.

Another chip designed for both ligation and transformation having 16 fluidic access vias, 91 valves and 23 actuation vias that allow microfluidic flow and control was also fabricated (figure not shown). The volume of the three sets of mixing rings was 6, 30 and $60 \mathrm{nl}$, respectively. In order to make large volume mixers without increasing the size of the rings, we increased the depth of the mixer channels to $50 \mu \mathrm{m}$, while the depth of the channels in the pumping area remained at $10 \mu \mathrm{m}$.

For the construction of the mould structures with two different channel depths, we first spin-coated negative photoresist SU-8 50 on a silicon wafer at $2300 \mathrm{rpm}$ for $45 \mathrm{~s}$, followed by mask exposure and development to make the $50 \mu \mathrm{m}$ channels. After hard baking for $1 \mathrm{~h}$ at $150{ }^{\circ} \mathrm{C}$, we spin-coated positive photoresist (Shipley SJR 5740) at $2200 \mathrm{rpm}$ for $1 \mathrm{~min}$, followed by careful mask alignment, exposure and development. This provided the second $10 \mu \mathrm{m}$ of 5740 layer. These mould channels were rounded at $135^{\circ} \mathrm{C}$ for $15 \mathrm{~min}$. Another mould for the actuation layer was made by spinning negative photoresist SU-8 2025 on a separate wafer at $3000 \mathrm{rpm}$ for $45 \mathrm{~s}$ with a resulting height $23 \mu \mathrm{m}$, followed by mask exposure and development. The devices were fabricated by bonding together two layers of two-part cure silicone (GE Silicone RTV615) cast from the photoresist moulds. The silicone process was the same, except that $1800 \mathrm{rpm}$ for $1 \mathrm{~min}$ was used for the control layer.

\subsection{System setup and pneumatic control of the microfluidic chip}

The chip was mounted on an inverted microscope (Nikon Eclipse TE2000-S). Fluorescence excitation was provided by a mercury lamp (100 W). A FITC filter set (Ex465-495, DM 505, BA 515-555) was used and the image was recorded by using a PC controlled colour digital camera (Sony DFW-V500).

Each actuation line on the chip was connected with a stainless steel pin (New England Small Tube, Litchfield, NH) and polyethylene tubing to an external solenoid valve controlled by a digital data I/O card (CCA, PPC1-DIO32HS; National Instruments, Austin, TX). Regulated external pressure was provided to the normally closed port, allowing the control channel to be pressurized or vented to atmosphere by switching the miniature valve. The fluidic vias for the introduction and collection of sample and buffer were connected to an external pressure source through polypropylene tips (Multiplex tips, Sorenson BioScience, Inc., West Salt Lake City, Utah). A typical pressure for driving liquid inside the chip was 0.5 to $2.0 \mathrm{psi}(1 \mathrm{psi}=6.89 \mathrm{kPa})$. All the valve actuation lines were filled with fluid and each control line was connected to the pressure source. The working pressure for the actuation channels was below 5 psi. All the valves were closed before loading the reagents.

\subsection{Ligation procedure on chip}

The target DNA was first loaded on the chip through the 'DNA' port by opening valves 4 and 7. Once the DNA solution flowed through the whole channel, valve 7 was closed. The chamber was dead-end-filled by pushing the air into the gas-permeable chip, then valve 4 was closed. By the same method, the vectors were loaded through the 'vector' port by operating valves 5 and 7, and the enzyme were loaded through the 'enzyme' port by operating valves 6 and 7. After 
the chambers were filled with reagents, valves 1 and 3 were opened, and nuclease free water was loaded through the 'water' port to push the reagents into the mixing rings. Then the three solutions were mixed by opening and closing the pumping valves 9,10 , and 11 sequentially. The chip was incubated at $37^{\circ} \mathrm{C}$ for $15 \mathrm{~min}$ on a thermal plate and then kept at room temperature to allow the ligation of the target DNA and the vector to be carried on. Finally, valves 1, 3, and 8 were opened, and the ligation products at the 'output' ports collected by applying $5 \mu 1$ of distilled water for each output port. Then the recovered ligation products were mixed with $20 \mu \mathrm{l}$ of competent cells and $80 \mu \mathrm{l}$ of SOC medium was added to each recovered ligation product. All the samples, $105 \mu \mathrm{l}$ of each, were loaded on antibiotic containing agar plates.

\subsection{Material for ligation}

Linearized plasmid vector pNEB205A containing ampicillin resistant gene and USER ${ }^{\mathrm{TM}}$ enzyme (uracil-specific excision reagent) (New England BioLabs) were used for the ligation procedure. NovaBlue Singles ${ }^{\mathrm{TM}}$ competent cells (Novagen) were used for the confirmation of the ligation procedure with the conventional off chip method. For the preparation of target DNA, GFP coding gene was amplified with conventional PCR. Thermal cycling conditions were as follows. Initial denaturing, $94{ }^{\circ} \mathrm{C}(2 \mathrm{~min}), 25$ cycles of DNA denaturing, $94{ }^{\circ} \mathrm{C}(30 \mathrm{~s})$; primer annealing, $61^{\circ} \mathrm{C}(45 \mathrm{~s})$; dNTP polymerizing, $72{ }^{\circ} \mathrm{C}$ (2 min); final extension, $72^{\circ} \mathrm{C}(7 \mathrm{~min})$. The primer set for 882 bp target DNA containing GFP gene containing region was 5'-GGAGACAUATGACCATGATTACGCCAAG-3' for forward and 5' GGGAAAGUCGCTCAGTTGGAATTCTACG-3' for reverse. The PCR cocktail was $0.5 \mu 1$ $\left(0.5 \mathrm{ng} \mu \mathrm{l}^{-1}\right)$ of pGFP vector (BD Biosciences), $1 \mu \mathrm{l}\left(25 \mathrm{pmol} \mu \mathrm{1}^{-1}\right)$ of each forward and reverse primer, $1 \mu \mathrm{l}$ (200 $\mu \mathrm{M}$ each) of dNTP mix (Roche), $5 \mu \mathrm{l}$ of $10 \times \mathrm{PCR}$ buffer and $0.25 \mu \mathrm{l}$ $(5 U / \mu 1)$ of Taq polymerase (Roche) in $50 \mu 1$ of reaction volume.

\subsection{Preparation of the selection medium}

A selective medium was prepared for the blue and white screening method of transformed cells on a Luria Bertani (LB) agar plate with ampicillin, IPTG and X-gal. Tryptone (10 g), yeast extract $(5 \mathrm{~g}), \mathrm{NaCl}(10 \mathrm{~g})$, agar $(15 \mathrm{~g})$ were dissolved in distilled water with the final volume 11 . The $\mathrm{pH}$ was adjusted to 7.0 with $\mathrm{NaOH}$. After autoclaving and cooling down to $55^{\circ} \mathrm{C}, 100 \mathrm{mg}$ of ampicillin (final concentration $100 \mu \mathrm{g} \mathrm{ml}^{-1}$ ) was added with $1 \mathrm{ml}$ of IPTG $(100 \mathrm{mM})$ and $2 \mathrm{ml}$ of X-gal (20 $\mathrm{mg} \mathrm{ml}^{-1}$ in dimethylfomamide) per litre.

\subsection{Transformation procedure on the chip}

The competent cells were loaded on the chip through the 'cell in' port by opening valves 4 and 5. Once the cell solution flowed through the whole channel, valve 5 was closed. The chamber was dead-end-filled by pushing the air into the gas-permeable chip, then valve 4 was closed. After the chambers were filled with cells, valve 1 was opened, then, plasmid DNA was loaded through the 'DNA in' port to push the reagents into the mixing rings. Then the two solutions were mixed by operating valves 7,8 , and 9 sequentially for mixing. The chip was kept at $0{ }^{\circ} \mathrm{C}$ during the loading and the mixing procedure, then the temperature was increased to $42{ }^{\circ} \mathrm{C}$ for $30 \mathrm{~s}$, and decreased to $0^{\circ} \mathrm{C}$ for 2 min to allow the transformation of the plasmid DNA into the competent cells. Finally, valves 1, 3, and 6 were opened, and the transformation products were collected at the 'output' ports. 
Table 1. DNA ligation on a microfluidic chip.

\begin{tabular}{|c|c|c|c|c|}
\hline Chip & Process $^{\mathrm{a}}$ & Number of colonies ${ }^{b}$ & Colony forming unit $/ \mu \mathrm{g} \mathrm{DNA}^{\mathrm{c}}$ & Efficiency $(\%)^{\mathrm{d}}$ \\
\hline \multirow[t]{4}{*}{1} & 1 & 1 & $8.0 \times 10^{4}$ & 5.6 \\
\hline & 2 & 0 & - & - \\
\hline & 3 & 0 & - & - \\
\hline & Positive $^{\mathrm{e}}$ & 448 & $1.4 \times 10^{6}$ & 100 \\
\hline \multirow[t]{4}{*}{2} & 1 & 2 & $1.6 \times 10^{5}$ & 11.5 \\
\hline & 2 & 0 & - & - \\
\hline & 3 & 1 & $8.0 \times 10^{4}$ & 5.8 \\
\hline & Positive & 437 & $1.4 \times 10^{6}$ & 100 \\
\hline \multirow[t]{4}{*}{3} & 1 & 2 & $1.6 \times 10^{5}$ & 11.1 \\
\hline & 2 & 1 & $8.0 \times 10^{4}$ & 5.6 \\
\hline & 3 & 0 & - & - \\
\hline & Positive & 453 & $1.4 \times 10^{6}$ & 100 \\
\hline \multirow[t]{4}{*}{4} & 1 & 2 & $1.6 \times 10^{5}$ & 11.6 \\
\hline & 2 & 2 & $1.6 \times 10^{5}$ & 11.6 \\
\hline & 3 & 3 & $2.4 \times 10^{5}$ & 17.4 \\
\hline & Positive & 436 & $1.4 \times 10^{6}$ & 100 \\
\hline \multirow[t]{4}{*}{5} & 1 & 3 & $2.4 \times 10^{5}$ & 16.3 \\
\hline & 2 & 3 & $2.4 \times 10^{5}$ & 16.3 \\
\hline & 3 & 2 & $1.6 \times 10^{5}$ & 11.0 \\
\hline & Positive & 462 & $1.5 \times 10^{6}$ & 100 \\
\hline \multirow[t]{4}{*}{6} & 1 & 2 & $1.6 \times 10^{5}$ & 10.5 \\
\hline & 2 & 2 & $1.6 \times 10^{5}$ & 10.5 \\
\hline & 3 & 2 & $1.6 \times 10^{5}$ & 10.5 \\
\hline & Positive & 482 & $1.5 \times 10^{6}$ & 100 \\
\hline
\end{tabular}

a There are three parallel processes on a chip.

${ }^{b}$ Colonies are counted on a selective agar medium after the ligation on a chip followed by the transformation off the chip. $50 \mu \mathrm{l}$ of cells $\left(10^{6}\right.$ cells $\left./ \mu 1\right)$ were used for the confirmation of the ligation.

c $12.6 \mathrm{pg}$ of DNA was used for each on chip gene transformation. For positive controls of conventional methods $315 \mathrm{pg}$ of DNA was used.

${ }^{\mathrm{d}}$ Ligation efficiency is calculated as on chip CFU $/ \mu \mathrm{g}$ DNA over off chip CFU $/ \mu \mathrm{g}$ DNA with the conventional transformation procedure. For off chip experiments, $1 \mu \mathrm{l}$ of target DNA, $1 \mu \mathrm{l}$ of vector and $1 \mu \mathrm{l}$ of enzyme were mixed, then the incubation process was carried out. Using $50 \mu \mathrm{l}$ of cells $\left(10^{6}\right.$ cells $\left./ \mu \mathrm{l}\right), 10^{7}$ DNA molecules were transformed.

${ }^{\mathrm{e}}$ Positive control is the ligation result carried out with the conventional method.

\section{Results and discussion}

The basic linear process for the ligation that was implemented consists of loading and metering target DNA, vector and enzyme, mixing together and recovery of the ligated samples from the chip. The incubation step for the ligation was carried out on a thermal stage or a heat block. The procedure for a single instance of these operations is illustrated in figure 1(C). The batch processing took place in a linear fashion; valves and cross-junctions were used to load different segments of a channel with three reagents: target DNA, linear vector, and enzyme. Because of the low Reynolds number, diffusion-controlled mixing in such a channel is impractically slow $[2,18]$. Therefore, the entire $6 \mathrm{nl}$ reaction volume was loaded into a rotary mixer, i.e. a ring with a peristaltic pump, allowing rapid mixing [12]. The ligation mixture was incubated on a thermal controller at $37^{\circ} \mathrm{C}$ for $15 \mathrm{~min}$ followed by room temperature incubation further 


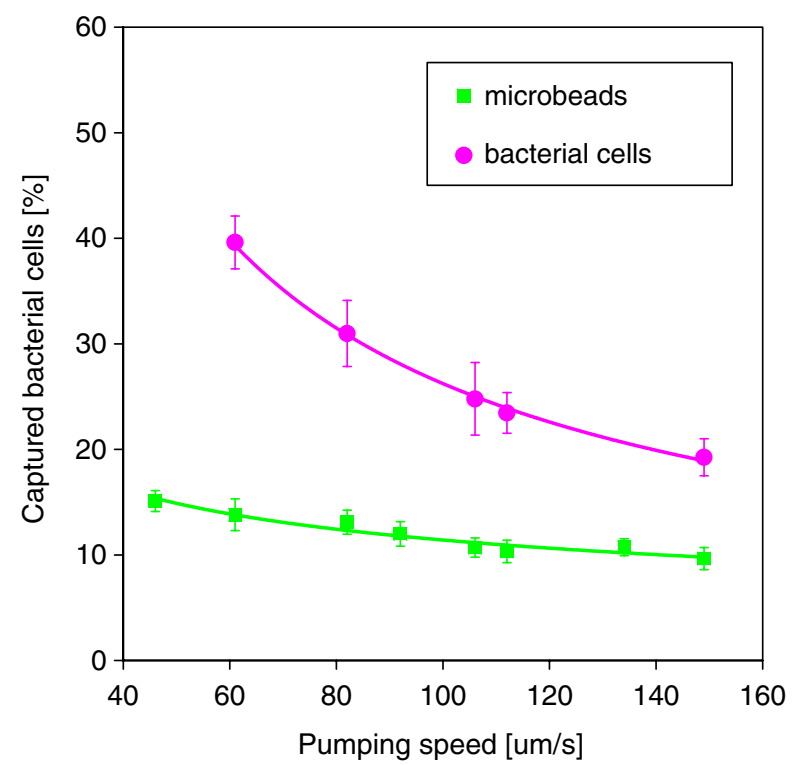

Figure 3. Evaluation of cell damage during the pumping process on the microfluidic chips. : E.coli bacterial cell; $\square$ : polystyrene microbead. E. coli cells containing enhanced green fluorescent protein (EGFP) were prepared and loaded onto the rotary pump. Cells captured under the microvalve regions after $30 \mathrm{~s}$ of the microvalve operation were counted and the damage rate was calculated compared to the total numbers of the cells loaded into the rotary mixer rings. Damaged cells exhibited distorted structures, reduced fluorescence and no discernable vital motion. Fluorescent microbeads, $2.3 \mu \mathrm{m}$, were used for as the control experiments. The percentage of the actually damaged cells on the microchip during the transformation process would be higher than this evaluation data because the competent cells are more fragile than the normal bacterial cells.

(This figure is in colour only in the electronic version)

15 min. To verify the ligation of the target DNA, we recovered the ligated products from the chip and plated them on agar medium with the blue-white screening method.

We ligated target DNA on more than six different chips (table 1). Each chip was capable of parallel processing with the same number of valve operations as for a single process (figure 1). The highest yield was $2.4 \times 10^{5}$ of colony forming unit (CFU)/ $\mu$ g of DNA with $17.4 \%$ of the highest ligation efficiency showing $11.1 \pm 3.8 \%$ of average efficiency compared to the conventional tube method. A further six chips were used as negative controls in which water was loaded instead of the target DNA; no white colony was present in any of these cases. These results show that it is possible to accomplish enzymatic ligation for molecular biology with nanolitres of the target DNA and vectors on a chip and thereby reduce the sample amounts of the ligation process by three orders of magnitude over conventional methods.

This parallel scheme allows each processor to be customized. We designed three processors on a chip for gene transformation to meter different volumes of samples, to facilitate the evaluation of the optimal conditions of the process (figure 2). The volumes of cell solution used in the top, middle and bottom processors were $1.25,1.50$ and $1.75 \mathrm{nl}$, respectively. The total volumes of each rotary reactor were $2.5,3.0$, and $3.5 \mathrm{nl}$, so $1.25,1.50$ and $1.75 \mathrm{nl}$ of plasmid DNA or vector were added to the cell volumes, respectively.

We successfully transformed plasmid DNA to chemically treated competent cells on nine different chips (figure 2 and table 2). For six of these chips we confirmed increased ligation efficiency from $8.9 \pm 0.5 \%$ to $12.9 \pm 2.9 \%$ and $19.8 \pm 3.4 \%$ with $2.5,3$, and $3.5 \mathrm{nl}$ of $1: 1$ mixture 
Table 2. Transformation on a microfluidic chip.

\begin{tabular}{|c|c|c|c|c|}
\hline Chip & Process $^{\mathrm{a}}$ & Number of colonies ${ }^{b}$ & Colony forming unit $/ \mu \mathrm{g} \mathrm{DNA}^{\mathrm{c}}$ & Efficiency $(\%)^{\mathrm{d}}$ \\
\hline \multirow[t]{4}{*}{1} & 1 & 0 & - & - \\
\hline & 2 & 2 & $3.3 \times 10^{6}$ & 14.1 \\
\hline & 3 & 3 & $4.3 \times 10^{6}$ & 18.4 \\
\hline & Positive & 468 & $2.3 \times 10^{7}$ & 100 \\
\hline \multirow[t]{4}{*}{2} & 1 & 1 & $2.0 \times 10^{6}$ & 8.2 \\
\hline & 2 & 2 & $3.3 \times 10^{6}$ & 13.6 \\
\hline & 3 & 3 & $4.3 \times 10^{6}$ & 17.7 \\
\hline & Positive & 486 & $2.4 \times 10^{7}$ & 100 \\
\hline \multirow[t]{4}{*}{3} & 1 & 0 & - & - \\
\hline & 2 & 2 & $3.3 \times 10^{6}$ & 14.4 \\
\hline & 3 & 2 & $2.9 \times 10^{6}$ & 12.5 \\
\hline & Positive & 458 & $2.3 \times 10^{7}$ & 100 \\
\hline \multirow[t]{4}{*}{4} & 1 & 1 & $2.0 \times 10^{6}$ & 9.3 \\
\hline & 2 & 1 & $1.7 \times 10^{6}$ & 7.7 \\
\hline & 3 & 3 & $4.3 \times 10^{6}$ & 19.9 \\
\hline & Positive & 432 & $2.1 \times 10^{7}$ & 100 \\
\hline \multirow[t]{4}{*}{5} & 1 & 1 & $2.0 \times 10^{6}$ & 9.1 \\
\hline & 2 & 2 & $3.3 \times 10^{6}$ & 14.9 \\
\hline & 3 & 3 & $4.3 \times 10^{6}$ & 19.5 \\
\hline & Positive & 442 & $2.2 \times 10^{7}$ & 100 \\
\hline \multirow[t]{4}{*}{6} & 1 & 1 & $2.0 \times 10^{6}$ & 8.8 \\
\hline & 2 & 2 & $3.3 \times 10^{6}$ & 14.5 \\
\hline & 3 & 2 & $2.9 \times 10^{6}$ & 12.6 \\
\hline & Positive & 454 & $2.3 \times 10^{7}$ & 100 \\
\hline
\end{tabular}

a There are three parallel processes on a chip with different reaction volumes, i.e., $2.5,3.0$, and $3.5 \mathrm{nl}$ with $1.0 \times 10^{5}, 1.2 \times 10^{5}$, and $1.4 \times 10^{5}$ of DNA molecules and $2.5 \times 10^{3}, 3.0 \times 10^{3}$, and $3.5 \times 10^{3}$ of cell for process 1,2 , and 3 , respectively.

${ }^{\mathrm{b}}$ Colonies are counted on a selective medium after the transformation on chip. The transformed cells were recovered from the chip.

${ }^{c} 0.5 \mathrm{pg}, 0.6 \mathrm{pg}$ and $0.7 \mathrm{pg}$ of DNA was used for process 1,2 , and 3 respectively (figure 2). For positive control $1 \mu \mathrm{l}$ of DNA (200.0 pg of DNA) and $50 \mu \mathrm{l}$ of cells (at least $10^{6}$ cells $/ \mu \mathrm{l}$ ) were used. After the heat shock, $250 \mu \mathrm{l}$ of SOC medium was added to the transformed cells and $30 \mu \mathrm{l}$ of the sample was loaded on the plate.

${ }^{\mathrm{d}}$ Efficiency is calculated as on chip CFU/ $\mu \mathrm{g}$ DNA over off chip CFU/ $\mu \mathrm{g}$ DNA.

of plasmid DNA and competent cells. We interpret the increased transformation efficiency with the increased total volume of the reaction as possibly due to damage to competent cells during the active mixing process or to thermal fluctuations when loading material onto the chip. Figure 3 shows the evaluation of the viability of cells during the mechanical pumping process. The number of bacterial cells captured under the valve region in the microfluidic channel was reduced from about $40 \%$ to $20 \%$ with increased pumping speed of the fluid from $61 \mu \mathrm{m} \mathrm{s}^{-1}$ ( $1 \mathrm{~Hz}$ of the sequential operation of the three microvalves for a rotary mixer) to $149 \mu \mathrm{m} \mathrm{s}^{-1}$ $(5 \mathrm{~Hz})$. We therefore assume that $20 \%-30 \%$ of the cells could be damaged during the pumping process. We improved the on chip transformation efficiency with a slightly modified chip design (table 3; the chip picture is not shown). This chip has decreased the DNA to cell ratio from 40:1 to $25: 1$, with $6.0 \times 10^{5}$ DNA molecules and $2.4 \times 10^{4}$ competent cells.

In conclusion, we have shown that it is possible to conduct fundamental molecular biology steps on an operated microfluidic chip with mechanically operated valve systems. Restriction 
Table 3. Transformation on a microfluidic chip with increased transformation efficiency.

\begin{tabular}{|c|c|c|c|c|}
\hline Chip & Process $^{\mathrm{a}}$ & Number of colonies $^{\mathrm{b}}$ & Colony forming unit $/ \mu \mathrm{g} \mathrm{DNA}^{\mathrm{c}}$ & Efficiency $(\%)$ \\
\hline \multirow[t]{4}{*}{1} & 1 & 30 & $1.0 \times 10^{7}$ & 47.5 \\
\hline & 2 & 18 & $6.0 \times 10^{6}$ & 28.5 \\
\hline & 3 & 7 & $2.3 \times 10^{6}$ & 11.1 \\
\hline & Positive & 2104 & $2.1 \times 10^{7}$ & 100 \\
\hline \multirow[t]{4}{*}{2} & 1 & 19 & $6.3 \times 10^{6}$ & 27.3 \\
\hline & 2 & 12 & $4.0 \times 10^{6}$ & 17.2 \\
\hline & 3 & 23 & $7.7 \times 10^{6}$ & 33.1 \\
\hline & Positive & 2318 & $2.3 \times 10^{7}$ & 100 \\
\hline \multirow[t]{4}{*}{3} & 1 & 10 & $3.3 \times 10^{6}$ & 14.7 \\
\hline & 2 & 17 & $5.7 \times 10^{6}$ & 24.9 \\
\hline & 3 & 28 & $9.3 \times 10^{6}$ & 41.0 \\
\hline & Positive & 2273 & $2.3 \times 10^{7}$ & 100 \\
\hline
\end{tabular}

a There are three parallel processes on a chip with the same reaction volume for each process. $6 \mathrm{nl}$ of plasmid DNA $\left(0.5 \mathrm{ng} \mu \mathrm{l}^{-1}\right)$ and $24 \mathrm{nl}$ of competent cells $\left(10^{6}\right.$ cells $\left.\mu \mathrm{l}^{-1}\right)$ were mixed on the microfluidic chip with $6.0 \times 10^{6}$ DNA molecules and $2.4 \times 10^{4}$ competent cells.

${ }^{\mathrm{b}}$ Colonies are counted on selective medium after the transformation on chip. The transformed cells were recovered from the chip and plated on agar media.

c $3.0 \mathrm{pg}$ of DNA was used for each on chip gene transformation. For positive controls, $1 \mu \mathrm{l}$ of DNA ( $0.5 \mathrm{ng}$ of DNA) and $50 \mu \mathrm{l}$ of cells (at least $10^{6}$ cells $\mu \mathrm{l}^{-1}$ ) were mixed in a tube and a heat shock process was carried out with the off chip method. Then, $250 \mu 1$ of SOC medium was added and $60 \mu \mathrm{l}$ of the sample was loaded on an agar plate.

of plasmids and ligation of them on a microfluidic chip were carried out with nanolitre volumes. Moreover, it has been demonstrated that introducing competent cells and conducting transformation with the heat shock method in nanolitre volume is available in microfluidic systems. These chips represent general processors for a molecular biology laboratory. There are several potential uses for a miniaturized microfluidic system for DNA ligation and gene transformation in more complicated biotechnology problems such as genomic DNA or cDNA libraries on a chip, and biophysical studies with limited target molecules.

\section{Acknowledgments}

This work was supported in part by the National Science Foundation (NSF), the National Institute of Health grant NIH R01 H6002644-01A1, and Department of Defense Advanced Research Projects Agency (DARPA).

\section{References}

[1] Nguyen N-T and Wereley S T 2002 Fundamentals and Applications of Microfluidics (Boston, MA: Artech House)

[2] Squires T M and Quake S R 2005 Rev. Mod. Phys. 77 977-1026

[3] Mandel M and Higa A 1970 J. Mol. Biol. 53 159-62

[4] Cohen S N, Chang A C Y and Hsu L 1972 Proc. Natl Acad. Sci. USA $692210-4$

[5] Hanahan D 1983 J. Mol. Biol. 166 557-80

[6] Neumann E, Schaefer-Ridder M, Wang Y and Hofschneider P H 1982 EMBO J. 1 841-5

[7] Dower W J, Miller J F and Ragsdale C W 1988 Nucleic Acids Res. 16 6127-45

[8] Lin Y C and Huang M Y 2001 J. Biomech. Microeng. 11 542-7

[9] Harrison D J, Majid E, Attiya S and Jiang G 2001 Proc. uTAS 2001 Symp. ed J M Ramsey and A van den Berg, pp 10-2

[10] Lin Y C, Li M and Wu C C 2004 Lab Chip 4 104-8 
[11] Unger M A, Chou H P, Thorsen T, Scherer A and Quake S R 2000 Science 288 113-6

[12] Chou H P, Unger M A and Quake S R 2001 Biomed. Microdev. 3 323-33

[13] Fu A Y, Chou H P, Spence C, Arnold F H and Quake S R 2002 Anal. Chem. 74 2451-7

[14] Liu J, Hansen C L and Quake S R 2003 Anal. Chem. 75 4718-23

[15] Hong J W, Studer V, Hang G, Anderson W F and Quake S R 2004 Nat. Biotech. 22 435-9

[16] Hansen C L, Skordalakes E, Berger J M and Quake S R 2002 Proc. Natl Acad. Sci. USA 99 16531-6

[17] Studer V, Hang G, Anderson W F and Quake S R 2004 J. Appl. Phys. 95 393-8

[18] Brody J P, Yager P, Goldstein R E and Austin R H 1996 Biophys. J. 71 3430-41 